\title{
Soybean Yield Loss to Sudden Death Syndrome in Relation to Symptom Expression and Root Colonization by Fusarium solani f. sp. glycines
}

\author{
Y. Luo, K. Hildebrand, S. K. Chong, O. Myers, and J. S. Russin, Department of Plant, Soil and General Agri- \\ culture, Center for Excellence in Soybean Research, Teaching and Outreach, Southern Illinois University, Carbon- \\ dale 62901-4415
}

\begin{abstract}
Luo, Y., Hildebrand, K., Chong, S. K., Myers, O., and Russin, J. S. 2000. Soybean yield loss to sudden death syndrome in relation to symptom expression and root colonization by Fusarium solani f. sp. glycines. Plant Dis. 84:914-920.

Field studies were conducted to determine the relationships between soybean yield and foliar disease index (FDX) of sudden death syndrome (SDS) as well as root colonization by Fusarium solani f. sp. glycines, the causal agent. Single-row plots in a soybean field with relatively uniform SDS incidence and severity were identified at growth stage R6 on cultivar Pioneer 9492 in DeSoto, IL, in 1997 and 1998. For each plot, foliar disease index (FDX), yield, and yield components were determined. In 1997, linear relationships between yield ( $Y$, grams per meter of row) and FDX were obtained from the wide-row $(Y=207.84-1.09$ FDX) and narrow-row $(Y=$ $126.66-0.745$ FDX) plots, respectively. A linear relationship $(Y=124.23-1.11$ FDX) also was observed in 1998. Increase in each FDX unit caused yield loss from 18 to $29 \mathrm{~kg} / \mathrm{ha}(0.7-1.1$ $\mathrm{g} / \mathrm{m}$ of row). FDX was negatively correlated with seed weight (grams per plant) in both years and with seed size (grams per 100 seeds) in 1997. A no-tilled field at Southern Illinois University planted to soybean cultivar Asgrow 5403 was divided into 25 plots in 1997 and 40 plots in 1998. Root samples were taken from each plot at five or six sampling times during the seasons. Roots were used to isolate and enumerate $F$. solani f. sp. glycines on a selective medium to obtain the CFU. FDX was assessed and soybean yield was obtained from each plot. Soybean yield correlated negatively with FDX in both years. Both yield and FDX correlated significantly with CFU from slightly before growth stage R1 to R2 in both years, and with area under the pathogen population curve (AUPC) in 1997. An increase in one unit of AUPC or CFU per gram of root at R6 was associated with yield loss of 0.19 or $0.014 \%$, respectively.
\end{abstract}

Additional keywords: soilborne disease

Sudden death syndrome (SDS) of soybean (Glycine max (L.) Merrill), caused by Fusarium solani f. sp. glycines (19), is an important disease in some soybean production areas in the United States. It can cause significant yield loss depending on cultivar susceptibility, cultural practices employed, and soil moisture and temperature conditions $(6,19,23,24,28)$. Yield losses in the United States typically range from 5 to $15 \%(19,24)$. Total losses from 1988 to 1994 were estimated at $175,619 \mathrm{t}$ and 280,000 $\mathrm{t}$ in the northern and southern regions of the United States, respectively $(2,19,27)$

The effect of SDS on yield depends on many factors. Root infection generally occurs in seedlings when high soil moisture and cool temperature coexist (19).

Corresponding author: Yong Luo

E-mail: yluo@uckac.edu

Current address of Y. Luo: University of California, Kearney Agricultural Center, Parlier 93648.

Accepted for publication 24 April 2000.

Publication no. D-2000-0612-03R

(c) 2000 The American Phytopathological Society
Foliar symptoms are not expressed until reproductive stages (19), depending upon soil environment (22), planting date (8), and cultivar susceptibility $(11,23)$. Severe disease during early soybean reproductive stages can reduce yield by inducing flower and pod abortion, which decreases seed number $(4,6,18,24,25)$. Disease that occurs during the pod-filling stages reduces yield by decreasing seed size $(8,24)$. Disease severity generally does not increase once plants have reached the full pod stage (R6) (3). The relationship between the extent of root infection and foliar severity and yield loss is poorly understood (19). This information is crucial in determining yield loss to SDS and selection of resistant cultivars $(4,12,19)$. The objective of this study was to examine the relationships between soybean yield and both SDS foliar symptoms and root colonization.

\section{MATERIALS AND METHODS}

Study 1: Foliar disease and soybean yield. Studies were conducted during 1997 and 1998 in a field in DeSoto, IL, that had a history of SDS. The field size was 4.8 ha, and it had been cropped to corn in 1996. The field was in corn-soybean rotation before 1996. The soybean cultivar Pioneer
9492 was planted no-till on 20 May 1997 and 21 May 1998. Pioneer 9492 is in maturity group 4.9 and has moderate resistance to SDS and resistance to soybean cyst nematode (SCN) (Heterodera glycines) races 3 and 14 (4). Planting density in both years was 27 plants per m row. In 1997, 76-cm (wide-row) and 38-cm (narrow-row) plantings were used in the field. In 1998, only the 76-cm row was used. Fertilizer applied at planting consisted of phosphorus at $44.8 \mathrm{~kg} / \mathrm{ha}$ and potassium at $67.3 \mathrm{~kg} / \mathrm{ha}$ in each season according to soil test recommendations. Soil type was identified as a Camden silt (7). Soil pH at midseason was 6.8 in 1997 and 7.0 in 1998. Soil organic matter measured at midseason was $2.6 \%$ in 1997 and $1.39 \%$ in 1998 . No herbicides or irrigation were applied in either year.

Single-row plots were established when plants reached growth stage R6. Individual plots were 5 to $7 \mathrm{~m}$ in length and were selected based on uniformity of SDS foliar symptoms. Forty-one plots were established in the wide-row planting and 18 plots were established in the narrow-row planting in 1997. Seventy-two plots were established in the wide-row planting in 1998. In all three tests, plots represented the range of disease severity levels observed in the fields. Three control plots (no foliar disease) also were identified for each test. In 1998, the eggs of $H$. glycines per $100 \mathrm{~cm}^{3}$ of soil were counted for each of 121 samples 3 weeks after planting using the method of Niblack et al. (14). The correlation between number of eggs and yield from these plots was determined using the CORR procedure of SAS (Version 7.0, SAS Institute, Cary, NC).

Foliar disease incidence (FDI) and severity (FDS) of SDS were assessed for each plot. FDI was assessed as the percentage of plants showing symptoms, while FDS was assessed on a 0 to 9 scale based on the percentage of leaf area chlorotic, necrotic, or defoliated (4): $0=$ no detectable leaf symptoms; $1=1$ to $10 \%$ chlorotic or 1 to $5 \%$ necrotic; $2=10$ to $20 \%$ chlorotic or less than $10 \%$ necrotic; $3=20$ to $40 \%$ chlorotic or 10 to $20 \%$ necrotic; $4=$ 40 to $60 \%$ chlorotic or 20 to $40 \%$ necrotic; $5=$ greater than $60 \%$ chlorotic or greater than $40 \%$ necrotic; $6=$ up to one-third premature defoliation; $7=$ one-third to two-thirds premature defoliation; $8=$ greater than two-thirds premature defolia- 
tion; and 9 = plants prematurely dead. A foliar disease index (FDX) also was calculated as described by Gibson et al. (4) in which FDX = FDI $\times$ FDS/9.

At harvest, plants from a 1-m length of row in each plot were removed. The number of plants in each sample was recorded, and three representative plants were selected and processed separately as described below. The plants also were used to assess root symptoms caused by $H$. glycines. The remaining plants from the $1-\mathrm{m}$ sample were dried at $64^{\circ} \mathrm{C}$ for $48 \mathrm{~h}$, then seeds were threshed and weighed. The weight of 100 seeds from each plot was calculated as the mean of three 100-seed subsamples.

The three-plant subsamples selected from the 1-m samples were processed to determine yield components. The number of pods for each plant was determined before drying, and the number of seeds and seed weight were determined after drying at $64^{\circ} \mathrm{C}$ for $48 \mathrm{~h}$. Mean values for these parameters were obtained from the three plants.

Data from narrow- and wide-row plots in 1997 and from the wide-row plots in 1998 were analyzed separately. The relationship between foliar disease index (FDX) and yield $(Y)$ from 1-m samples was examined using the REG procedure of SAS. Homogeneity of regression (5) was tested to determine the significance of differences between regression coefficients. Correlation between FDX and weight of 100 seeds was also examined. Yield components from the three-plant subsamples included seed weight (g per plant), seeds per plant, seeds per pod, and pods per plant. The linear regressions between FDX and some variables were determined using the REG procedure of SAS when scatter plot examination showed a clear relationship. Comparisons in FDX and yield between the 2 years were conducted using LSD $(\alpha=0.05)$.

Study 2: Root colonization and soybean yield. Experiments were conducted at Southern Illinois University, Agricultural Research Center, Carbondale, in a field that was no-tilled from 1996 to 1998 and in corn-soybean rotation prior to 1996. The experimental area measured 30 by 30 $\mathrm{m}$ in 1997 and was enlarged to 30 by $45 \mathrm{~m}$ in 1998. The soybean cultivar Asgrow 5403 was planted both years. This cultivar is in maturity group 5.3, susceptible to SDS, and resistant to soybean cyst nematode races 3 and 14 . The soil was identified as a Weir silt loam (7). No herbicides or irrigation were applied in either year. Soybean was planted at a row spacing of 0.76 $\mathrm{m}$ and a density of 27 plants per meter of row in both years. Planting dates were 16 May 1997 and 15 May 1998. The field was divided into 25 plots in 1997 and 40 plots in 1998. Each plot was 6 by $6 \mathrm{~m}$ and contained 8 rows. The two outer rows in each plot were used for destructive root sampling, and the two inner rows were used for
Table 1. Dates of soybean root samplings in 1997 and 1998 and the corresponding soybean growth stages on cultivar Asgrow 5403, Carbondale, IL

\begin{tabular}{lccccc}
\hline & \multicolumn{2}{c}{1997} & & \multicolumn{2}{c}{1998} \\
\cline { 2 - 3 } \cline { 5 - 6 } Sampling & Date & Growth stage $^{\mathbf{2}}$ & & Date & Growth stage \\
\hline 1 & 11 June & V3 & & 11 June & V3 \\
2 & 28 June & V6 & & 9 July & V8.5 \\
3 & 8 July & V8.5 & & 4 Aug. & R2 \\
4 & 24 July & R1 & & 21 Aug. & R5.5 \\
5 & 21 Aug. & R5.5 & & 15 Sep. & R8 \\
6 & 19 Sep. & R8 & & \\
\hline
\end{tabular}

${ }^{\mathrm{z}}$ Growth stages according to Fehr et al. (3).
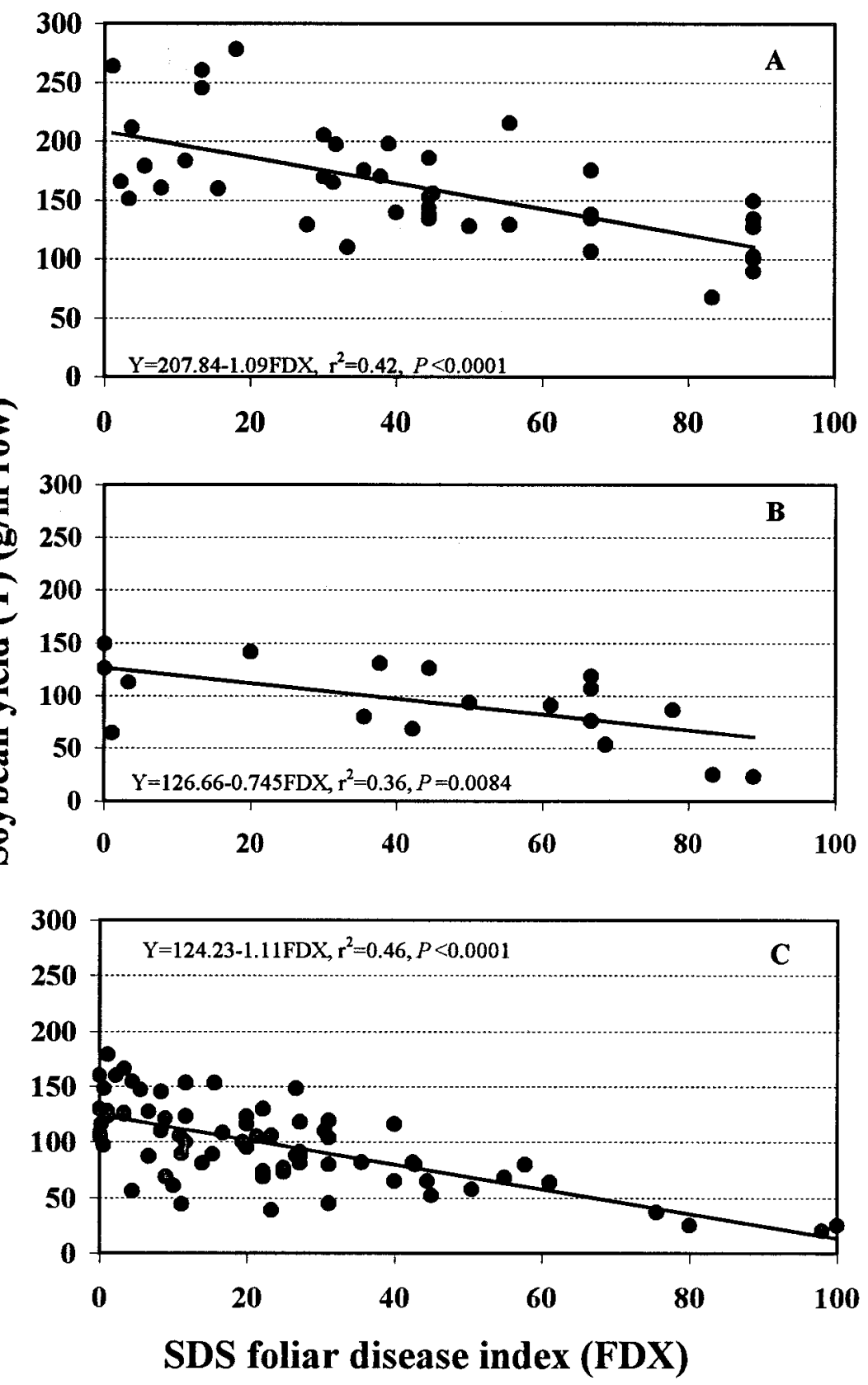

Fig. 1. Relationships between foliar disease index (FDX) of soybean sudden death syndrome (SDS) at growth stage R6 and soybean yield. Observations were from single-row plots in a field in DeSoto, IL, in 1997 and 1998. (A) observations from wide-row plots (76-cm row spacing) in 1997. (B) observations from narrow-row plots (38-cm row spacing) in 1997. (C) Observations from wide-row plots (76-cm row spacing) in 1998. 
foliar disease assessment and yield determination.

The soil $\mathrm{pH}$ at 3 weeks after planting was 6.63 in 1997 and 7.10 in 1998. Soil organic matter at midseason was $1.32 \%$ in 1997 and $1.03 \%$ in 1998. Eggs of H. glycines per $100 \mathrm{~cm}^{3}$ of soil were counted 3 weeks after planting using the same method as described in study 1 . The correlation between number of eggs and yield from these plots was determined using the CORR procedure of SAS.

At each sampling time, three plants were chosen at random from the two outer rows in each plot. These plants were also used to determine root symptoms caused by $H$. glycines. Roots were removed from soil, lateral roots were pruned, and the three taproots were combined as one sample to be used for pathogen isolation. Root samples were taken six times in 1997 and five times in 1998. Soybean growth stages for each sampling date are listed in Table 1.

In the laboratory, taproots were washed thoroughly with water, surface-sterilized in $0.0525 \%$ sodium hypochlorite for $2 \mathrm{~min}$, rinsed three times with sterile distilled water, then dried in an incubator at $28^{\circ} \mathrm{C}$ for $24 \mathrm{~h}$ (for small roots) or $48 \mathrm{~h}$ (for large roots). The three dried taproots from each plot were ground together using a Wiley mill (Thomas Scientific Inc., Swedesboro, NJ) to pass a 40-mesh screen. The mill and screen tube were cleaned thoroughly between samples with a paintbrush and delicate task wipers to minimize contamination. Ground taproot tissue was diluted with $200 \mathrm{ml}$ (for small taproots) or 2,000 $\mathrm{ml}$ (for large taproots) of distilled water. Root dilution $(1 \mathrm{ml})$ for each sample was spread on the medium selective for $F$. solani f. sp. glycines $(13,21)$. Five plates

Table 2. Relation between foliar disease index (FDX) of sudden death syndrome and soybean yield components on the cultivar Pioneer 9492 at growth stage $\mathrm{R}^{\mathrm{z}}$

\begin{tabular}{|c|c|c|c|c|}
\hline Relation with FDX & $\boldsymbol{F}$ & Prob $>F$ & Regression equation & $r^{2}$ \\
\hline \multicolumn{5}{|l|}{ Wide-row plots, 1997} \\
\hline Seed size (SS, g/100 seeds) & 44.819 & 0.0001 & $\mathrm{SS}=14.25-0.05116 \mathrm{FDX}$ & 0.49 \\
\hline Seeds per pod (SN, seeds/pod) & 1.177 & 0.2838 & & \\
\hline Seed weight per pod (SP, g/pod) & 28.789 & 0.0001 & $\mathrm{SP}=0.31-0.0013 \mathrm{FDX}$ & 0.39 \\
\hline Seed weight per plant (SW, g/plant) & 28.329 & 0.0001 & $\mathrm{SW}=9.13-0.0579 \mathrm{FDX}$ & 0.39 \\
\hline Pods per plant (PD, pods/plant) & 7.114 & 0.0106 & $\mathrm{PD}=29.75-0.0969 \mathrm{FDX}$ & 0.14 \\
\hline \multicolumn{5}{|l|}{ Narrow-row plots, 1997} \\
\hline Seed size (SS, g/100 seeds) & 21.610 & 0.0002 & $\mathrm{SS}=14.26-0.0482 \mathrm{FDX}$ & 0.53 \\
\hline Seeds per pod (SN, seeds/pod) & 0.431 & 0.5195 & & \\
\hline Seed weight per pod (SP, g/pod) & 4.955 & 0.0383 & $\mathrm{SP}=0.29-0.0008 \mathrm{FDX}$ & 0.21 \\
\hline Seed weight per plant (SW, g/plant) & 23.191 & 0.0001 & $\mathrm{SW}=7.32-0.0575 \mathrm{FDX}$ & 0.55 \\
\hline Pods per plant (PD, pods/plant) & 17.076 & 0.0006 & $\mathrm{PD}=25.38-0.1607 \mathrm{FDX}$ & 0.47 \\
\hline \multicolumn{5}{|l|}{ Wide-row plots, 1998} \\
\hline Seed size (SS, g/100 seeds) & 3.761 & 0.0565 & & \\
\hline Seeds per pod (SN, seeds/pod) & 7.716 & 0.0070 & $\mathrm{SN}=2.04-0.00445 \mathrm{FDX}$ & 0.10 \\
\hline Seed weight per pod (SP, g/pod) & 11.865 & 0.0010 & $\mathrm{SP}=0.214-0.00056 \mathrm{FDX}$ & 0.14 \\
\hline Seed weight per plant (SW, g/plant) & 64.514 & 0.0001 & $\mathrm{SW}=8.02-0.08119 \mathrm{FDX}$ & 0.48 \\
\hline Pods per plant (PD, pods/plant) & 11.336 & 0.0012 & $\mathrm{PD}=55.91-0.3805 \mathrm{FDX}$ & 0.14 \\
\hline
\end{tabular}

${ }^{z}$ Data were obtained from a 2-year field study in Desoto, IL.

Table 3. Correlation coefficients showing relationships between soybean root colonization by Fusarium solani f. sp. glycines (transformed CFU), area under the pathogen population curve (AUPC), disease index for foliar symptom (FDX) of sudden death syndrome, and yield for 1997w

\begin{tabular}{lcccccc}
\hline & \multicolumn{5}{c}{ Correlation coefficient $(\boldsymbol{R})$} \\
\cline { 2 - 7 } & Sampling 4 & Sampling 5 & Sampling 6 & AUPC & \multicolumn{1}{c}{ FDX } & Yield (kg/ha) \\
\hline Sampling 3 (CFU) & -0.160 & 0.098 & -0.053 & 0.236 & $0.631^{* * * y}$ & $-0.485^{*}$ \\
Sampling 4 (CFU) & 1.000 & 0.050 & 0.198 & 0.389 & -0.002 & -0.210 \\
Sampling 5 (CFU) & & 1.000 & 0.214 & $0.751^{* *}$ & 0.362 & -0.385 \\
Sampling 6 (CFU) & & 1.000 & 0.406 & 0.364 & -0.390 \\
AUPC & & & 1.000 & $0.580^{* * z}$ & $-0.679^{* *}$ \\
FDX & & & & 1.000 & $-0.733^{* *}$ \\
\hline
\end{tabular}

${ }^{\mathrm{w}}$ Data were obtained from 25 plots in a field at Southern Illinois University in 1997.

${ }^{\mathrm{x}}$ First and second samplings in 1997 are not included in correlations because no colony of Fusarium solani f. sp. glycines was found.

${ }^{y} R$ values followed by $*$ and $* *$ are significant at $P \leq 0.05$ and $P \leq 0.01$, respectively.

${ }^{\mathrm{z}}$ AUPCs calculated from sampling 1 to 5 in 1997 were used to determine correlation between FDX and AUPC.

Table 4. Correlation coefficients showing relationships between soybean root colonization by Fusarium solani f. sp. glycines (transformed CFU), area under the pathogen population curve (AUPC), disease index for foliar symptom (FDX) of sudden death syndrome, and yield for $1998^{\mathrm{x}}$

\begin{tabular}{|c|c|c|c|c|c|c|c|}
\hline \multirow[b]{2}{*}{1998} & \multicolumn{7}{|c|}{ Correlation coefficient $(R)$} \\
\hline & Sampling 2 & Sampling 3 & Sampling 4 & Sampling 5 & AUPC & FDX & Yield (kg/ha) \\
\hline Sampling 1 (CFU) & 0.239 & -0.053 & -0.013 & 0.031 & $0.477 * * \mathrm{y}$ & -0.038 & 0.102 \\
\hline Sampling 2 (CFU) & 1.000 & -0.221 & 0.031 & 0.486 & $0.622 * *$ & -0.048 & 0.185 \\
\hline Sampling 3 (CFU) & & 1.000 & -0.100 & 0.014 & 0.126 & $0.629 * *$ & $-0.601 * *$ \\
\hline Sampling 4 (CFU) & & & 1.000 & 0.025 & $0.361 * *$ & -0.033 & 0.088 \\
\hline Sampling 5 (CFU) & & & & 1.000 & $0.402 * * \mathrm{z}$ & 0.144 & -0.075 \\
\hline AUPC & & & & & 1.000 & 0.109 & -0.033 \\
\hline FDX & & & & & & 1.000 & $-0.803^{* *}$ \\
\hline
\end{tabular}

${ }^{x}$ Data were obtained from 40 plots in a field at Southern Illinois University in 1998.

y $R$ values followed by $*$ and $* *$ are significant at $P \leq 0.05$ and $P \leq 0.01$, respectively.

${ }^{\mathrm{z}}$ AUPCs calculated from sampling 1 to 4 in 1998 were used to determine correlation between FDX and AUPC. 
were used for each root dilution. The plates were incubated at room temperature $(25 \pm$ $2{ }^{\circ} \mathrm{C}$ ) for 10 days. Colonies of $F$. solani $\mathrm{f}$. sp. glycines were identified by morphology and conidia. Analysis by random amplified polymorphic DNA (RAPD) markers (1) was conducted early in each season for five root samples to confirm that the isolates collected from the fields were the SDS causal agent. The number of colonies on each plate was used to determine CFU per gram of root for each sampling time.

Incidence and severity of foliar SDS symptoms were assessed at growth stage R6 from three sections of a row ( $1 \mathrm{~m}$ in length) chosen randomly from the two inner rows in each plot. Methods for assessing incidence and severity, as well as calculating disease index, were as described for the study 1 . Seed yield was determined from 3-m row sections from the two inner rows of each plot. Plants were machine-threshed, and plot yields were calculated as kilograms per hectare.

The CFU per gram of root for each plot at each sampling date was calculated by averaging colony counts from five plates and was transformed using the formula: $\log _{10}(\mathrm{CFU}+1)$. This variable was examined over all sampling times to produce a root colonization progress curve for each plot, which then was used to determine the area under the pathogen population curve (AUPC) as calculated by Euler's rectangular integration method (17). Correlation analyses for all variables, including transformed CFU at each sampling date, AUPC, FDX, and yield, were carried out using the CORR procedure of SAS. For the correlations between FDX and AUPC, the AUPCs were calculated from the first through fifth sampling in 1997 and the first through fourth sampling in 1998. Regression analyses were conducted using the REG procedure of SAS when correlations were significant $(P \leq 0.05)$. A geographic information system (GIS) was used to depict the field distribution of yield and root colonization using the computer software SURFER (Golden Software, Inc., Golden, CO). Comparisons in FDX, yield, and AUPC between 2 years were conducted using $\operatorname{LSD}(\alpha=0.05)$.

\section{RESULTS}

Study 1. Foliar disease and soybean yield. SDS foliar symptoms appeared at growth stage R5 in 1997 and slightly before R5 in 1998. The field showed SDS disease foci of various sizes and severities in both seasons. At each focus, disease incidence was relatively uniform.

Values for FDX ranged from 0 to 90 in 1997 and 0 to 100 in 1998. There was a linear relationship between yield and FDX (Fig. 1). For each unit increase in FDX, soybean yield decreased $0.74-1.11 \mathrm{~g}$ per plant (Fig. 1). Regression coefficients did not differ between wide- and narrow-row plots in $1997(t=-1.9220, n=55)$ and wide-row plots in 1997 and 1998 ( $t=$ $0.1304, n=109$ ). Overall yield was higher in 1997 than in 1998 (Fig.1A and C).

Although values for most yield components declined as the value for FDX increased, this relationship was more variable for some components than for others (Table 2). Seed size was significantly related to FDX in two of three studies (wide- and narrow-row plots in 1997). Seed weight per plant decreased as FDX increased in both years. The coefficients of determination for the regression of seed weight per pod on FDX were low and variable. The regression coefficients relating number of pods per plant to FDX were lower for wide-row plots in both years than for narrow-row plots in 1997. For each
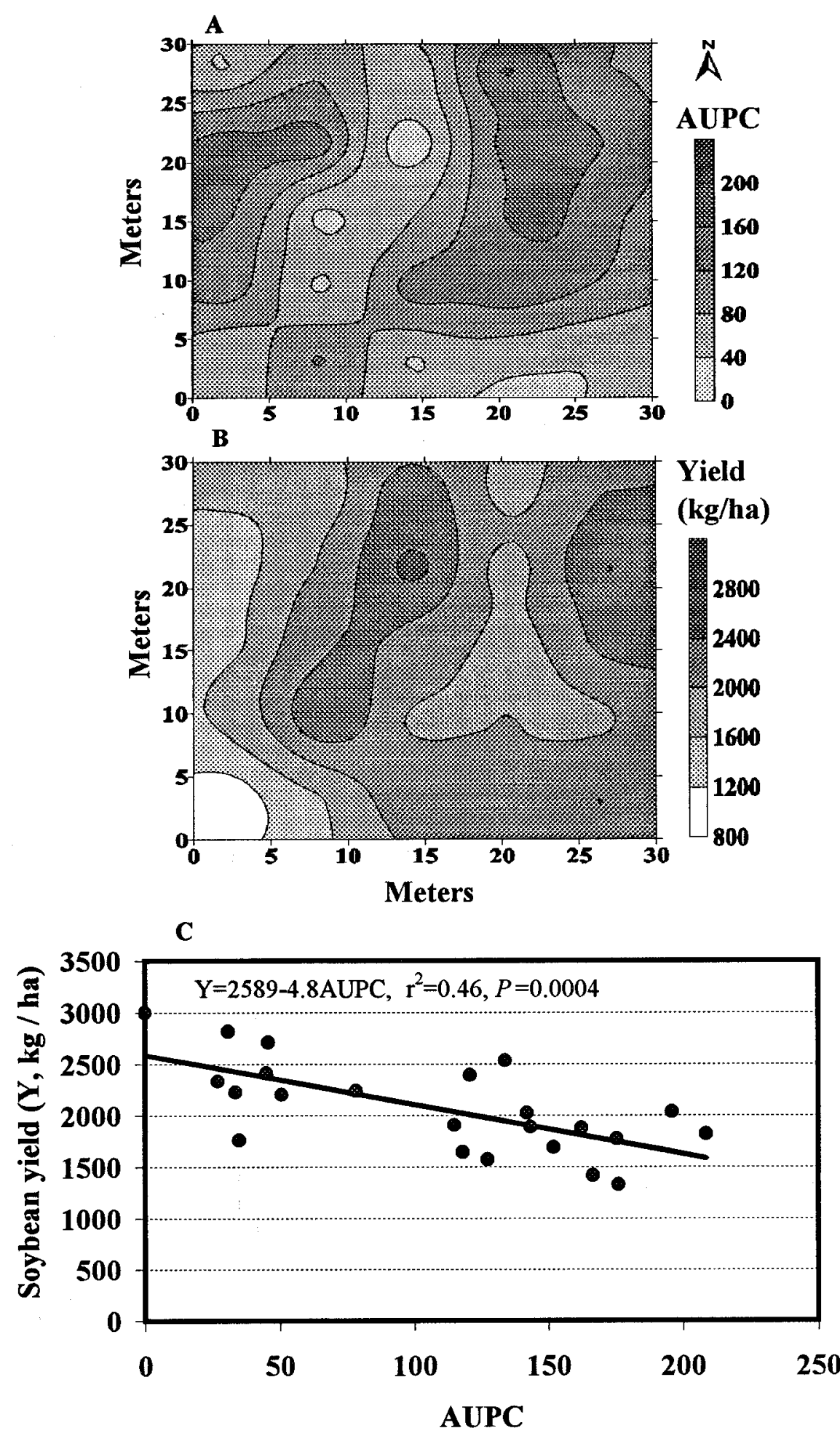

Fig. 2. GIS maps showing field distributions for area under the Fusarium solani f. sp. glycines population curve (AUPC) (A) and soybean yield (B) in a field at Southern Illinois University in 1997. The field was divided into 25 plots $(6 \times 6 \mathrm{~m}$ each). A linear relationship between these two variables was obtained (C). 
increase of 10 FDX units, yield per plant was reduced by 0.57 to $0.81 \mathrm{~g}$ and weight of 100 seeds was reduced by 0.48 to $0.51 \mathrm{~g}$ (Table 2).

Study 2. Root colonization and soybean yield. Root colonization by $F$. solani f. sp. glycines was first detectable at the third sampling in 1997 but at the first sampling in 1998. Therefore, onset of root colonization was earlier in 1998 than in 1997.
In 1997, FDX correlated positively with root colonization at the third sampling date and with AUPC (calculated from first through fifth samplings) (Tables 3 and 4). In 1998, FDX correlated positively with root colonization only at the third root sampling date (Tables 3 and 4).

The GIS map of root colonization in 1997 showed two foci in the west and northeast portions of the field, where AUPC values were greater than 160 (Fig.
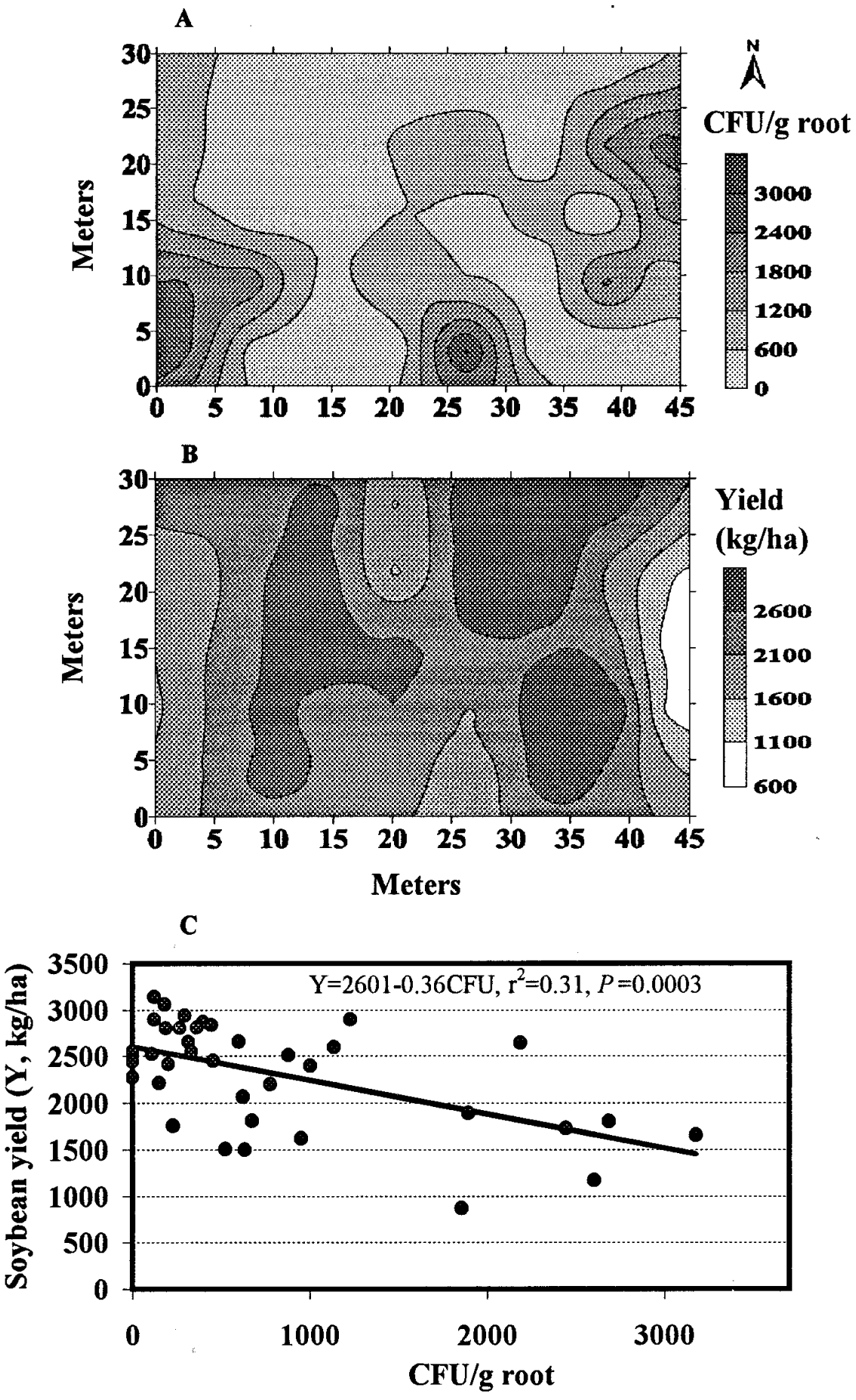

Fig. 3. GIS maps showing field distributions for root colonization by Fusarium solani f. sp. glycines (CFU per g of root) at growth stage R2 (A) and soybean yield (B) in 1998 in the same field depicted in Figure 2. The field was enlarged to $30 \times 45 \mathrm{~m}$ with 40 plots $(6 \times 6 \mathrm{~m}$ each). A linear relationship between these two variables was obtained $(\mathbf{C})$.

2A) and yields ranged from 1,200 to 2,000 $\mathrm{kg} /$ ha (Fig. 2B). Area of root colonization in the central west and southeast portions of the field (Fig. 2A) corresponded with higher yields (Fig. 2B). Soybean yield correlated negatively with AUPC (Fig. $2 \mathrm{C})$. Soybean yield also correlated negatively with CFU at the third sampling date (growth stage V8.5) (Tables 3 and 4), but not with CFUs at other root samplings. There was no significant correlation in CFU between any two samplings.

In 1998, there were three foci, at the northeast, southwest, and south-central portions of the field, that had AUPC values greater than 2,400 CFU/g of root at the third sampling (Fig. 3A), which corresponded to reduced yields ranged from 600 to 2,100 $\mathrm{kg} / \mathrm{ha}$ (Fig. 3B). Yield was inversely related to inoculum density (Fig. 3C).

Regression analysis demonstrated that a unit increase in AUPC caused about 4.8 $\mathrm{kg} / \mathrm{ha}$ or $0.19 \%$ yield loss (Fig. 2C). Yield loss caused by increase in each CFU per gram of root at R6 was about $0.36 \mathrm{~kg} / \mathrm{ha}$ or $0.014 \%$ (Fig. 3C).

There was a difference in root colonization between the 2 years. Because $F$. solani f. sp. glycines was recovered from roots at the third sampling date in 1997 and the first sampling date in 1998, the AUPCs ranged from 0 to $208($ mean $=107)$ in 1997 and from 41 to 316 (mean = 174) in 1998 . The CFU at the last sampling ranged from 0 to $5,563 \mathrm{CFU} / \mathrm{g}$ of root $($ mean $=1,368)$ in 1997 but from 199 to $6,335 \mathrm{CFU} / \mathrm{g}$ of root (mean $=1,906)$ in 1998. FDX at R6 ranged from 0 to 55.6 (mean $=15.1)$ in 1997 and from 0 to $88.9($ mean $=23.7)$ in 1998 .

The average FDX was higher in 1997 than in 1998 in study 1 . The mean yield was higher in the wide-row plots in 1997 than in the narrow-row plots in 1997 and in the plots in 1998 in study 1 (Table 5). No difference in either FDX or yield between the 2 years was found in study 2 (Table 5). However, AUPC in 1998 was significantly higher than in 1997 (Table 5).

Mean numbers of $H$. glycines eggs early in the growing season were 5,697 \pm 341 and $9,326 \pm 793$ per $100 \mathrm{~cm}^{3}$ of soil in the fields of study 1 and 2, respectively. However, there was no correlation between $H$. glycines egg number and yield in either field $(P=$ $0.07, R=0.1525$ in study 1 and $P=0.89, R$ $=0.0208$ in study 2). No foliar and root symptoms attributable to $H$. glycines were observed at either site in either year.

\section{DISCUSSION}

Gibson et al. (4) reported that an increase of $1 \%$ in SDS incidence resulted in 7 to $34 \mathrm{~kg} / \mathrm{ha}$ ( 0.1 to $0.5 \mathrm{bu} / \mathrm{A})$ yield loss. Njiti et al. (16) reported that for each unit increase in foliar disease severity, yield was reduced by 12 to $22 \%$. Hirrel (9) used linear regression equations to describe yield as a function of disease severity for different maturity groups. In general, reductions of about 538 to $1,277 \mathrm{~kg} / \mathrm{ha}$ and 
$874 \mathrm{~kg} / \mathrm{ha}$ for each unit increase in disease were reported for Arkansas and Illinois, respectively. The equations used 3,577 and $4,324 \mathrm{~kg} / \mathrm{ha}$ as the maximum yields (9). Our study reports that increase in each FDX caused 18 to $29 \mathrm{~kg} / \mathrm{ha}(0.7$ to $1.1 \mathrm{~g} / \mathrm{m}$ of row) yield loss. Because these results were from a moderately resistant cultivar, further studies of yield loss on cultivars with different susceptibility to SDS are needed.

Our results showed that foliar disease index correlated negatively with seed size and seed weight (grams per plant), which likely contributed to yield reduction. Previous studies showed that both reduced seed number and size largely account for yield loss to SDS $(6,8,24)$. We also found that reduction of seed size was significant in 1997 but not in 1998. Because reduced seed size is probably due to arrested plant development, premature plant death, impaired capacity of the diseased plant to of these (19), the observed variability in SDS development between the 2 years may explain the inconsistency.

In the second study, we determined that root colonization (CFU and/or AUPC), FDX, and yield were all correlated with each other on cultivar Asgrow 5403 in the 2 years. This study documented the quantitative relationship between root colonization by $F$. solani f. sp. glycines and soybean yield using analysis of pathogen temporal dynamics and spatial distribution in the field.

There are few studies that have examined the relationships among foliar disease, yield, and root colonization. Scherm and Yang (26) found no close correlation between root disease severity and foliar disease severity. Njiti et al. (15) reported significant but low to modest correlations between soybean taproot infection and severity of SDS foliar symptoms at growth stage R6. Rupe (20) found a positive correlation between root mass and leaf symptom severity. Different methods and assessment systems used in root infection may account for the variability of conclusions. Our study emphasized the dynamics of root colonization associated with spatial distribution in relation to soybean yield under field conditions. The CFU per gram produce seed dry matter, or a combination

of root may be the more sensitive measurement for root colonization than other measurements such as root infection severity (15).

Based on our observations in this study, it appeared that disease symptom severity might be more closely related to root colonization early in the season (before R1) than later in the season (after R3). Our previous field studies (10) also showed a significant correlation between FDX and early root colonization level (45 days after planting) for six soybean cultivars.

We observed that soybean yield was related to root colonization in certain circumstances depending on environment, cultivation, and pathogen development. Therefore, under controlled conditions, a greenhouse approach (11) for root colonization assessment may be useful to evaluate resistance to SDS. Determination of conditions for root colonization favorable to distinguish resistant cultivars may also be important.

This study demonstrated a linear decrease in soybean yield as SDS FDX increases. Yield loss resulted from reduction of several yield components related to foliar disease. Yield was also reduced as root colonization increased. Soybean yield, root colonization, and foliar disease index are all correlated with each other under certain conditions. These findings may be useful to explain the yield loss to SDS in the fields.

\section{ACKNOWLEDGMENTS}

This research was supported by the Illinois Council for Food and Agricultural Research (CFAR) grant no: 97I-02. We thank L. A. Achenbach and J. Patrick for identification of $F$. solani f. sp. glycines isolates using RAPD markers. We thank Jim Klein for his excellent field services. We also thank Allen Wrather, University of Missouri-Delta Center, for his review of this manuscript.

\section{LITERATURE CITED}

1. Achenbach, L. A., Patrick, J., and Gray, L. 1996. Use of RAPD markers as a diagnostic tool for the identification of Fusarium solani isolates that cause soybean sudden death syndrome. Plant Dis. 80:1228-1232.

2. Doupnik, B., Jr. 1993. Soybean production and disease loss estimates for North Central United States from 1989 to 1991. Plant Dis. 77:1170-1171.

3. Fehr, W. R., Caviness, C. E., Burmood, D. T., and Pennington, J. S. 1971. Stage of development descriptions for soybeans, Glycine

Table 5. Foliar disease index (FDX) of soybean sudden death syndrome (SDS), yield, and area under the population curve (AUPC) of root colonization by Fusarium solani f. sp. glycines ${ }^{\mathrm{w}}$

\begin{tabular}{llccrc}
\hline & Year & No. samples $^{\mathbf{x}}$ & FDX & Yield $^{\mathbf{y}}$ & \multicolumn{1}{c}{ AUPC $^{\text {SUd }}$} \\
\hline Study 1 & 1997 (wide rows) & 41 & $42.5 \mathrm{a}^{\mathrm{z}}$ & $161.4 \mathrm{a}$ & \\
& 1997 (narrow rows) & 17 & $45.2 \mathrm{a}$ & $92.9 \mathrm{~b}$ & \\
& 1998 & 72 & $23.2 \mathrm{~b}$ & $98.5 \mathrm{~b}$ & \\
Study 2 & 1997 & 25 & $15.1 \mathrm{a}$ & $2,069.6 \mathrm{a}$ & $107.9 \mathrm{~b}$ \\
& 1998 & 40 & $23.8 \mathrm{a}$ & $2,315.6 \mathrm{a}$ & $791.1 \mathrm{a}$ \\
\hline
\end{tabular}

${ }^{\text {w }}$ Studies were conducted at Southern Illinois University.

${ }^{x}$ Samples are number of rows in study 1 and number of plots in study 2 .

${ }^{\mathrm{y}}$ Yields are in grams per meter of row in study 1 and kilograms per hectare in study 2 .

${ }^{\mathrm{z}}$ Values in a column for each study followed by a letter in common are not significantly different at $P \leq 0.05$. $\max ($ L.) Merrill. Crop Sci. 2:929-931.

4. Gibson, P. T., Shenaut, M. A., Njiti, V. J., Suttner, R. J., and Myers, O., Jr. 1994. Soybean varietal response to sudden death syndrome. Am. Seed Trade Assoc., 24th Soybean Res. Conf. 24:20-40.

5. Gomez, K. A., and Gomez, A. A. 1984. Statistical Procedures for Agricultural Research 2nded. John Wiley \& Sons, New York.

6. Hartman, G. L., Noel, G. R., and Gray, L. E. 1995. Occurrence of soybean sudden death syndrome in east-central Illinois and associated yield losses. Plant Dis. 79:314-318.

7. Herman, R. J., Miles, C. C., Dungan, L. A., Currie, B. E., and Ice, P. W. 1979. Soil survey of Jackson County Illinois. Ill. Agric. Exp. Stn. Soil Rep. 106. University of Illinois at Urbana-Champaign College of Agriculture, Agriculture Experiment Station in cooperation with SCS, USDA.

8. Hershman, D. E., Hendrix, J. W., Stuckey, R. E., Bachi, P. R., and Henson, G. 1990. Influence of planting date and cultivar on soybean sudden death syndrome in Kentucky. Plant Dis. 74:761-766.

9. Hirrel, M. C. 1987. Sudden death syndrome of soybean: New insights into its development. Am. Seed Trade Assoc., 16th Soybean Res. Conf. 16:95-104.

10. Luo, Y., Myers, O., Lightfoot, D. A., and Schmidt, M. E. 1999. Root colonization of soybean cultivars in the field by Fusarium solani f. sp. glycines. Plant Dis. 83:11551159

11. Luo, Y., Myers, O., Lightfoot, D. A., Schmidt, M. E., and Achenbach, L. A. 1998. Effect of inoculum concentration of Fusarium solani f. sp. glycines on soybean cultivar susceptibility and incubation period of sudden death syndrome (SDS). (Abstr.) Proc. Am. Soc. Agron. 90:75.

12. Melgar, J., and Roy, K. W. 1994. Soybean sudden death syndrome: Cultivar reactions to inoculation in a controlled environment and host range and virulence of causal agent. Plant Dis. 78:265-268.

13. Nash, S. M., and Snyder, W. C. 1962. Quantitative estimation by plate counts of propagules of the bean root rot Fusarium in field soils. Phytopathology 52:567-572.

14. Niblack, T. L., Heinz, R. D., Smith, G. S., and Donald, P. A. 1993. Distribution, density, and diversity of Heterodera glycines in Missouri. J. Nematol. 25(4S):880-886.

15. Njiti, V. N., Suttner, R. J., Gray, L. E., Gibson, P. T., and Lightfoot, D. A. 1997. Rate-reducing resistance to Fusarium solani f. sp. phaseoli underlies field resistance to soybean sudden death syndrome. Crop Sci. 37:132138.

16. Njiti, V. N., Suttner, R. J., Shenaut, M. A., and Gibson, P. T. 1994. Soybean SDS effects on yield components. (Abstr.) Proc. Am. Soc. Agron. 86:128.

17. Rabbinge, R., Ward, S. A., and Van Laar, H. H. 1989. Simulation and Systems Management in Crop Protection. Center for Agricultural Publishing and Documentation (Pudoc), Wageningen, Netherlands.

18. Roy, K. W., Lawrence, G. W., Hodges, H. H., McLean, K. S., and Killebrew, J. F. 1989. Sudden death syndrome of soybean: Fusarium solani as incitant and relation of Heterodera glycines to disease severity. Phytopathology 79:191-197.

19. Roy, K. W., Rupe, J. C., Hershman, D. E., and Abney, T. S. 1997. Sudden death syndrome of soybean. Plant Dis. 81:1100-1111.

20. Rupe, J. C. 1989. Frequency and pathogenicity of Fusarium solani recovered from soybeans with sudden death syndrome. Plant Dis. 75:581-584.

21. Rupe, J. C., Becton, C. M., Williams, K. J., 
and Yount, P. 1996. Isolation, identification, and evaluation of fungi for the control of sudden death syndrome of soybean. Can. J. Plant Pathol. 18:1-6.

22. Rupe, J. C., and Gbur, E. E., Jr. 1995. Effect of plant age, maturity group, and the environment on disease progress of sudden death syndrome of soybean. Plant Dis. 79:139-143.

23. Rupe, J. C., Gbur, E. E., and Marx, D. M. 1991. Cultivar responses to sudden death syndrome of soybean. Plant Dis. 75:47-50.
24. Rupe, J. C., and Hartman, G. L. 1999. Sudden death syndrome. Pages 37-38 in: Compendium of Soybean Diseases. 4th ed. G. L. Hartman, J. B. Sinclair, and J. C. Rupe, eds. American Phytopathological Society, St. Paul, MN.

25. Rupe, J. C., Sabbe, W. E., Robbins, R. T., and Gbur, E. E., Jr. 1993. Soil and plant factors associated with sudden death syndrome of soybean. J. Prod. Agric. 6:218-221.

26. Scherm, H., and Yang, X. B. 1996. Development of sudden death syndrome of soybean in relation to soil temperature and soil wate matric potential. Phytopathology 86:642-649.

27. Wrather, J. A., Chambers, A. Y., Fox, J. A.,

Moore, W. F., and Sciumbato, G. L. 1995. Soybean disease loss estimated from the southern United States, 1974 to 1994. Plant Dis. 79:1076-1079.

28. Wrather, J. A., Kendig, S. R., and Anand, S C. 1995. Effects of tillage, cultivar, and planting date on percentage of soybean leaves with symptoms of sudden death syndrome. Plant Dis. 79:560-562. 